\title{
PENGARUH MASA TANAM TERHADAP KUALITAS RUMPUT LAUT, Kappaphycus alvarezii
}

\author{
Rohama Daud \\ Balai Penelitian dan Pengembangan Budidaya Air Payau \\ Jl. Makmur Dg. Sitakka No. 129, Maros 90512, Sulawesi Selatan \\ E-mail: litkanta@indosat.net.id
}

\section{ABSTRAK}

Budidaya rumput laut memliki peranan yang sangat penting dalam usaha meningkatkan produksi perikanan serta memenuhi kebutuhan pangan dan gizi. Beberapa kendala yang masih dijumpai di lapangan antara lain kualitas hasil panen yang masih rendah akibat pemanenan rumput laut yang lebih awal dari waktu panen yang seharusnya (6-7 minggu), akibat permintaan rumput laut cukup tinggi. Percobaan ini bertujuan untuk memperlihatkan kandungan nilai gizi rumput laut yang dipanen pada masa tanam 10, 20, dan 30 hari. Jenis rumput laut yang ditanam adalah Kappaphycus alvarezii yang dibudidayakan di sekitar perairan Teluk Maumere Desa Kojadoi Kecamatan Alok Timur Kabupaten Sikka, Nusa Tenggara Timur. Metode budidaya rumput laut yang digunakan adalah metode tali panjang (long line), dengan panjang tali 35 m sebanyak 750 bentangan. Jarak antara bentangan $1 \mathrm{~m}$, jarak tanam yang diaplikasikan adalah $15 \mathrm{~cm}$, dengan bobot awal bibit $50 \mathrm{~g}$. Setiap 10 hari sampel diambil secara acak untuk dianalisis proksimatnya (kadar air, protein, karbohidrat, serat, dan abu), sehingga diperoleh masa tanam 10, 20, dan 30 hari. Sebelum dianalisis, rumput laut tersebut dijemur selama 3 hari sampai kering. Untuk mengetahui kadar air, abu, lemak, dan serat kasar, rumput laut dianalisis dengan menggunakan metode gravimetrik, sedang kadar protein dan BETN dengan metode trimetri. Hasil penelitian menunjukkan bahwa kadar air, abu, lemak, dan bahan ekstrak tanpa nitrogen (BETN) menurun seiring dengan lamanya masa tanam, sedangkan kadar protein dan serat kasar meningkat seiring dengan lamanya masa tanam.

KATA KUNCI : masa tanam, rumput laut Kappaphycus alvarezii, kualitas rumput laut

\section{PENDAHULUAN}

Sebagai salah satu komoditas unggulan budidaya, rumput laut mempunyai potensi yang cukup besar untuk dikembangkan. Budidaya ini menggunakan modal kerja yang relatif kecil dengan teknologi yang sudah dikuasai dan diikuti oleh masa tanam yang relatif pendek 45 hari, sehingga memungkinkan usaha budidaya ini dapat meningkatkan pendapatan masyarakat setempat sekaligus menyerap tenaga kerja. Pada tahun 2011, produksi rumput laut secara keseluruhan mencapai 4.305.027 ton. Pada tahun 2012 KKP telah menargetkan produksi rumput laut sebesar 5.100.000 ton dan menjadikan Indonesia sebagai produsen utama rumput laut dunia (Pitakasari, 2012).

Selanjutnya produksi rumput laut Indonesia dalam kurun waktu 2002-2006 mengalami peningkatan yang cukup tinggi yakni 71,67\%/tahun di mana produksi rumput laut tahun 2002 adalah 223.080 ton meningkat menjadi 1.507.944 ton pada tahun 2006 (Nurdjana, 2007).

Rumput laut menjadi komoditas utama karena bisa cepat dipanen, teknologi budidayanya mudah diadopsi oleh masyarakat dan input produksi yang relatif kecil. Target produksi tersebut dapat dicapai melalui program ekstensifikasi pemanfaatan lahan potensial sekitar 4,5 juta ha; perbaikan teknologi budidaya sesuai pola musim dan karakterisasi lahan masing-masing kawasan budidaya sudah hanpir dikuasai.

Salah satu langkah akhir dalam suatu kegiatan budidaya rumput laut sebelum dipasarkan adalah panen. Panen rumput laut sebelum waktunya akan menurunkan kualitas rumput laut. Apabila panen dilakukan pada umur atau lama tanam kurang dari 45 hari pemeliharaan, maka rumput laut yang dihasilkan akan berkualitas rendah. Hal ini karagenan yang dikandungnya menjadi rendah dan kekuatan gel (gel strength) juga akan rendah, tetapi kadar airnya tinggi. Menurut Hadie et al. (2011), bahwa kualitas rumput laut 
yang memenuhi standar sangat ditentukan oleh proses budidayanya, di samping penanganan pasca panennya. Pemanenan hasil budidaya dilakukan minimal 6 minggu setelah pemeliharaan bibit. Pada saat panen dilakukan sortasi yang bertujuan untuk membersihkan hasil panen rumput laut dari benda-benda asing seperti pasir, garam, plastik rapia, dan jenis rumput laut lainnya (Parenrengi et al., 2011).

Dengan tingginya kebutuhan atau permintaan untuk memenuhi target produksi, dikhawatirkan banyak pembudidaya yang tidak memenuhi standar masa tanam rumput laut, yang hanya mengejar kuantitas tanpa memperhatikan kualitas.

Tujuan dari penelitian ini untuk memperlihatkan kualitas (kandungan nutrisi) rumput laut sehubungan dengan masa tanam rumput laut.

\section{METODE DAN BAHASAN}

Percobaan dilakukan di perairan Desa Kojadoi Kecamatan Alok Timur Kabupaten Sikka, Nusa Tenggara Timur pada bulan November 2011 sampai Januari 2011. Metode budidaya rumput laut yang digunakan adalah metode tali panjang (long line), dengan panjang tali $35 \mathrm{~m}$ sebanyak 750 bentangan. Jarak antara bentangan $1 \mathrm{~m}$. Jarak tanam yang diaplikasikan adalah $15 \mathrm{~cm}$, dengan bobot awal bibit $50 \mathrm{~g}$ (Pongmasak et al., 2011). Jenis rumput laut yang ditanam adalah Kappaphycus alvareziiyang diperoleh dari hasil budidaya masyarakat di sekitar perairan Teluk Maumere. Jumlah bentangan yang diamati sebanyak 750 bentangan. Setiap 10 hari diambil sampel diambil secara acak untuk dianalisis proksimatnya (kadar air, protein, karbohidrat, serat, dan abu), sehingga diperoleh masa tanam 10, 20, dan 30 hari. Sebelum dianalisis, rumput laut tersebut dijemur selama 3 hari sampai kering. Sebelum dikeringkan rumput laut dibersihkann dari kotoran dan tanaman penempel. Ciri rumput laut yang telah kering adalah warna rumput laut ungu keputih-putihan yang dilapisi dengan kristal garam. Untuk memisahkan garam dari rumput laut dilakukan dengan pengayakan. Untuk mengetahui kadar air, abu, lemak, dan serat kasar, rumput laut dianalisis di Laboratorium Nutrisi Balai Penelitian dan Pengembangan Budidaya Air Payau, Maros dengan menggunakan metode gravimetrik, sedang kadar protein dengan metode trimetri.

\section{BAHASAN}

Rumput laut mempunyai kandungan nutrisi cukup lengkap. Secara kimia rumput laut terdiri atas air $(27,8 \%)$; protein $(5,4 \%)$; karbohidrat $(33,3 \%)$; lemak $(8,6 \%)$; serat kasar (3\%); dan abu $(22,5 \%)$. Selain itu, rumput laut juga mengandung enzim, asam nukleat, asam amino, vitamin A, B, C, D, E, dan K, dan makro mineral seperti nitrogen, oksigen, kalsium, dan selenium, serta mikro mineral seperti zat besi, magnesium dan natrium. Kandungan asam amino, vitamin, dan mineral rumput laut mencapai 10-20 kali lipat dibanding dengan tanaman darat (Anonim, 2010a), namun tidak dijelaskan jenis rumput laut tersebut dan lama budidayanya. Sehingga waktu yang diperlukan oleh tanaman dalam mencapai tingkat kandungan bahan utama maksimal merupakan patokan dalam menentukan waktu panen.

Hasil analisis proksimat rumput laut, Kappaphycus alvarezii yang telah dilakukan disajikan pada Tabel 1 .

Dari Tabel 1 terlihat bahwa uji parameter dari rumput laut sampel yang dianalisis menunjukkan nilai kadar air yang diperoleh semakin menurun seiring dengan lamanya masa tanam, namun masih lebih rendah dari kadar air yang dilaporkan oleh Anonim (2010c) dan Eucheuma spinosum seperti terlihat pada Tabel 2. Tapi kandungan kadar air dari hasil yang telah disebutkan di atas, bergantung dari metode pengeringan yang dilakukan, yang penting kadar air tidak melebihi dari 35\% (Parenrengi et al., 2011). Demikian juga dengan kadar abu, lemak, dan bahan ekstrak tanpa nitrogen (BETN) menurun seiring dengan lamanya budidaya. Bahan ekstrak tanpa nitrogen yang dihasilkan berkisar $43,42 \%$ $45,42 \%$ cukup tinggi karena nilai ini termasuk kandungan karbohidrat, asam amino, dan vitamin.

Kadar abu rumput laut (K. alvarezii) yang diperoleh selama pengamatan yang nilainya berkisar 45,93\%-48,20\% masih lebih tinggi dibanding dengan kadar abu pada rumput laut yaitu 22,5\% (Anonim, 2010b) dan Eucheuma spinosum yaitu 14,21\% (Anonim, 2010c). Demikian juga dengan nilai kadar lemak rumput laut $K$. alvarezii $(0,05 \%-0,01 \%)$ lebih rendah dibanding dengan kadar rumput laut yang nilainya 8,6\% (Anonim, 2010b), dan kadar rumput laut Eucheuma spinosum dengan nilai 0,18\% (Anonim, 2010c).

Kadar protein (2,46\%-3,29\%) dan serat kasar (3,88\%-6,06\%) meningkat seiring dengan lamanya masa tanam (Tabel 2), 
Tabel 1. Proksimat analisis rumput laut, K. alvarezii dengan masa tanam berbeda

\begin{tabular}{lccc}
\hline \multicolumn{1}{c}{ Parameter } & 10 hari (\%) & 20 hari (\%) & 30 hari (\%) \\
\hline Air & 11,55 & 11,27 & 10,97 \\
Abu & 48,20 & 47,72 & 45,93 \\
Lemak & 0,05 & 0,02 & 0,01 \\
Protein & 2,46 & 2,79 & 3.29 \\
Serat kasar & 3,88 & 5,41 & 6,06 \\
BETN & 45,42 & 45,35 & 43,42 \\
\hline
\end{tabular}

Tabel 2. Komposisi kimia rumput laut Eucheuma spinosum

\begin{tabular}{lc}
\hline Komposisi kimia & Komposisi (\%) \\
\hline Kadar air & 21,90 \\
Protein & 5,12 \\
Lemak & 0,18 \\
Karbohidrat & 13,38 \\
Serat kasar & 1,39 \\
Abu & 14,21 \\
Karagenan & 65,75 \\
\hline
\end{tabular}

Sumber: $\quad$ Anonim (2010c)

tetapi masih rendah dibanding dengan kadar protein $(5,4 \%)$ dan serat kasar (3\%) rumput laut (Anonim, 2010b), juga lebih rendah dibanding kadar protein $(5,12 \%)$ dan serat kasar $(1,39 \%)$ rumput Eucheuma spinosum (Anonim, 2010c). Hal ini diduga karena masa tanam rumput laut yang diamati lebih singkat dari kedua rumput laut sebagai pembanding.

Selain mempertimbangkan umur pemeliharaan atau masa tanam, panen sebaiknya mempertimbangkan juga kondisi cuaca agar kualitas rumput laut yang dihasilkan akan terjamin. Pertumbuhan rumput laut selama pengamatan selama 30 hari pemeliharaan adalah 6,44\%/hari. Pertumbuhan alga 2\%-5\%/hari (Doty, 1973; Soegiarto et al., 1978; Aslan, 2008) dalam Loupatty et al., 2012); sedang Eucheuma cottoni 3\%/hari (Anggadiredja, 2008 dalam Loupatty et al., 2012).

Kisaran salinitas di lokasi budidaya berkisar 33,0-33,10 ppt yang fluktuasinya tidak besar. Menurut Pongmasak et al. (2011), bahwa fluktuasi salinitas di luar kisaran (32-34 ppt) akan menyebabkan rendahnya pertumbuhan dan cepatnya proses penuaan (aging process), yang baik berkisar 28-35 ppt (Parenrengi et al., 2011). Menurut Doty (1987) dalam Risjani (1999), rumput laut K. alvarezii mempunyai salinitas optimum yang berkisar antara 29-34 ppt, sedangkan menurut Kadi \& Atmadja (1988), salinitas optimalnya adalah 30-37 ppt,
Tabel 3. Analisis kualitas air sekitar perairan lokasi budidaya

\begin{tabular}{lc}
\hline \multicolumn{1}{c}{ Parameter } & Nilai Kisaran \\
\hline Nitrat $(\mathrm{mg} / \mathrm{L})$ & $0,0256-0,3482$ \\
Fosfat $(\mathrm{mg} / \mathrm{L})$ & $0,0142-0,0877$ \\
BOT $(\mathrm{mg} / \mathrm{L})$ & $73,06-83,59$ \\
Suhu $\left({ }^{\circ} \mathrm{C}\right)$ & $30,74-30,98$ \\
Salinitas $(\mathrm{ppt})$ & $33,0-33,10$ \\
$\mathrm{pH}$ & $6,9-7,89$ \\
\hline
\end{tabular}

sehingga dari segi kadar garam, lokasi pemeliharaan sangat sesuai untuk budidaya rumput laut K. alvarezii.

Fluktuasi suhu yang sangat tinggi akan membuat tanaman bibit menjadi stres sehingga memengaruhi laju pertumbuhan. Suhu yang layak bagi lokasi perairan budidaya rumput laut berkisar $26^{\circ} \mathrm{C}-29^{\circ} \mathrm{C}$ (Pongmasak et al., 2011). Dawes (1989) dalam Ask \& Azanza (2002) menyatakan bahwa rumput laut $K$. alvarezii dapat menolerir suhu antara $22^{\circ} \mathrm{C}-25^{\circ} \mathrm{C}$ tetapi optimum pada suhu berkisar antara $25^{\circ} \mathrm{C}$ 28C. Suhu perairan pada lokasi budidaya berkisar $30,74^{\circ} \mathrm{C}-$ $30,98^{\circ} \mathrm{C}$. Selanjutnya Pongmasak et al. (2011) mengatakan bahwa kenaikan suhu yang tinggi akan mengakibatkan talus rumput laut menjadi pucat, menjadi layu, dan mudah terserang penyakit.

pH menjadi faktor pembatas terhadap kehidupan dan keberadaan suatu tumbuhan. Walaupun air laut memiliki nilai $\mathrm{pH}$ yang relatif stabil tetapi dapat dipengaruhi oleh aktivitas fotosintesis, suhu, serta buangan industri dan rumah tangga. Nilai pH yang diperoleh pada lokasi budidaya adalah 6,9-7,89 diduga akibat kebiasaan masyarakat membuang langsung limbah rumah tangga ke laut. Menurut Pongmasak et al. (2011), bahwa pH yang optimum adalah berkisar 7,8-8,2.

Nutrien sangat berperan dalam pertumbuhan rumput laut khususnya kandungan nitrogen dan fosfat. Jalur pertumbuhan $K$. alvarezii berkorelasi sangat positif dengan kenaikan kandungan nitrogen di dalam tanaman dan lingkungan budidaya (Risjani, 1999). Kandungan nitrat dan fosfat di sekitar lokasi budidaya masing-masing berkisar 0,0256-0,3482 $\mathrm{mg} / \mathrm{L}$ dan 0,0142-0,0877 $\mathrm{mg} / \mathrm{L}$; sedang Loupatty et al., 2012 mendapatkan nilai nitrat dan fosfat di sekitar perairan budidaya rumput laut, Padina australis berkisar 0,57-1,13 mg/L dan 0,44-1,09 mg/L. 


\section{KESIMPULAN}

Dari analisis sampel yang dilakukan pada masa tanam 10, 20, dan 30 hari untuk mengetahui kandungan gizi rumput laut Kappaphycus alvarezii disimpulkan:

1. Kadar air, abu, lemak, dan bahan ekstrak tanpa nitrogen (BETN) menurun seiring dengan lamanya masa tanam

2. Kadar protein dan serat kasar meningkat seiring dengan lamanya masa tanam

\section{DAFTAR ACUAN}

Anonim. 2010a. http://www.tnol.co.id/id Bugar/10945 -manfaat rumput laut bagi kesehatan.html\# T43Wy1tlbDc

Anonim. 2010b. http://rumputlaut.web44.net/article/ kandu ngan-dan-manfaat-rumput-laut/

Anonim. 2010c. http://cinduatakacauhariujan.wordpress. com/2010/03/25/kandungan-gizi-manfaat-rumput laut/

Ask, E.I. \& Azanza, R.V. 2002. Advances in cultivation technology of commercial eucheumatoid species: a review with suggestions for future research. Aquaculture, 206: 257-277.

Hadie, W., Daud, R., \& Pantjara, B. 2011. Pemasyarakatan IPTEK budidaya rumput laut di Teluk Maumere Kabupaten Sikka, Nusa Tenggara Timur. Badan Penelitian dan Pengembangan Kelautan dan Perikanan. Pusat Penelitian dan Pengembangan Perikanan Budidaya. Jakarta.
Kadi, A. \& Atmadja, W.S. 1988. Rumput laut (alga): jenis, reproduksi, produksi budidaya, dan pasca panen. Puslitbang Oceanologi, $71 \mathrm{hlm}$.

Loupatty, J.W., Jamal, E., \& Hariyono. 2012. Laju pertumbuhan, produksi, dan kandungan alginat rumput laut Padina australis, yang dibudidaya di perairan Teluk Kotania. Program Studi Budidaya Perairan, Universitas Pattimura.

Nurdjana, M.L. 2007. Program pengembangan dan pemberdayaan perikanan budidaya lima tahun ke depan. Makalah disampaikan pada Rakernis Pusat Riset Perikanan Budidaya (PRPB). Yogyakarta, 26-27 Juli 2007. $29 \mathrm{hlm}$.

Parenrengi, A., Rachmansyah, \& Suryati, E. 2011. Budidaya rumput laut penghasil karaginan (karaginofit). Badan Penelitian dan Pengembangan Kelautan dan Perikanan. Kementerian kelautan dan Perikanan, Republik Indonesia. ISBN: 978-979-3692-21-0. $54 \mathrm{hlm}$.

Pitakasari, A.R. 2012. http://www.republika.co.id/berita/ ekonomi/makro/12/04/07/m23dyb-target-2012produksi-rumput-laut-capai-51 juta-ton

Pong-Masak, P.R., Parenrengi, A., Tjaronge, M., \& Rusman 2008. Protokol seleksi varietas bibit unggul rumput laut. Balai Penelitian dan Pengembangan Budidaya Air Payau. Pusat Penelitian dan Pengembangan Budidaya. Kementerian Kelautan dan Perikanan. 27 hlm.

Risjani, Y. 1999. An investigation of reverse and transport of nitrogen along the thallus of Eucheuma. Agritek, 7(4): 69-73. 